\title{
Induction of altered epigenetic regulation of the hepatic glucocorticoid receptor in the offspring of rats fed a protein-restricted diet during pregnancy suggests that reduced DNA methyltransferase-1 expression is involved in impaired DNA methylation and changes in histone modifications
}

\author{
Karen A. Lillycrop ${ }^{1}$, Jo L. Slater-Jefferies ${ }^{2}$, Mark A. Hanson ${ }^{2}$, Keith M. Godfrey ${ }^{2,3}$, Alan A. Jackson ${ }^{4}$ and \\ Graham C. Burdge ${ }^{2 *}$ \\ ${ }^{1}$ Development and Cell Biology, Biomedical Sciences Building, University of Southampton, Bassett Crescent East, Southampton \\ SO16 7PX, UK \\ ${ }^{2}$ Developmental Origins of Health and Disease Division, University of Southampton, Princess Anne Hospital, Coxford Road, \\ Southampton SO16 5YA, UK \\ ${ }^{3}$ MRC Epidemiology Resource Centre, Southampton General Hospital, Tremona Road, Southampton SO16 6YD, UK \\ ${ }^{4}$ Institute of Human Nutrition, Southampton General Hospital, Tremona Road, Southampton SO16 6YD, UK
}

(Received 14 July 2006 - Revised 12 December 2006 - Accepted 18 December 2006)

\begin{abstract}
Prenatal nutritional constraint induces an altered metabolic phenotype in the offspring which in humans confers an increased risk of non-communicable disease. Feeding a protein-restricted (PR) diet to pregnant rats causes hypomethylation of specific gene promoters in the offspring and alters the phenotype. We investigated how altered epigenetic regulation of the hepatic glucocorticoid receptor (GR) $1_{10}$ promoter is induced in the offspring. Rats were fed a control $(180 \mathrm{~g}$ casein $/ \mathrm{kg})$ or a PR $(90 \mathrm{~g}$ casein $/ \mathrm{kg})$ diet throughout pregnancy, and chow during lactation. Offspring were killed at postnatal day 34 ( $n 5$ per maternal dietary group). Methylation-sensitive PCR showed that GR $1_{10}$ promoter methylation was $33 \%$ lower $(P<0.001)$ and GR expression $84 \%$ higher $(P<0.05)$ in the PR offspring. Reverse transcription-PCR showed that DNA methyltransferase1 (Dnmt1) expression was $17 \%$ lower $(P<0 \cdot 05)$ in PR offspring, while Dnmt3a/b and methyl binding domain protein-2 expression was not altered. Thus hypomethylation of the GR1 $1_{10}$ promoter may result from lower capacity to methylate hemimethylated DNA during mitosis. Histone modifications which facilitate transcription were increased at the GR $1_{10}$ promoter (147-921\%, $\left.P<0 \cdot 001\right)$, while those that suppress methylation were decreased $(54 \%, P<0.01)$ or similar to controls. In human umbilical cord $(n 15)$, there was a 2 -fold difference between the highest and lowest level of GR1-C $\mathrm{C}_{\text {Total }}$ promoter methylation. Dnmt1, but not Dnmt3a, expression predicted $49 \%(P=0.003)$ of the variation in GR1-C $\mathrm{T}_{\text {Total }}$ promoter methylation. These findings suggest that induction in the offspring of altered epigenetic regulation of the hepatic GR $1_{10}$ promoter, and hence metabolic phenotype, may be due to reduced Dnmt1 expression.
\end{abstract}

Fetal programming: Epigenetic: Rat: Glucocorticoid receptor: Histones: Human

There is an increasing awareness that aspects of the prenatal environment such as maternal nutrition and stress levels provide cues that alter the phenotype of the fetus without overt reductions in fetal growth (Bateson et al. 2004). Such nutritional cues may operate within the normal range for the human population and contribute to the early origins of risk of chronic diseases such as the metabolic syndrome and CVD (Godfrey \& Barker, 2001). In rats, variations in phenotype can be induced by maternal undernutrition (Langley \& Jackson, 1994; Vickers et al. 2005) or increased intake of specific nutrients (Armitage et al. 2005). As in humans (Ravelli et al. 1998), the phenotype which is induced is dependent upon the timing of nutrient restriction during pregnancy or lactation (Remacle et al. 2004).

Induced changes to the phenotype which persist throughout the life span are likely to involve stable alterations to the expression of the genome. The offspring of rats fed a diet with a moderate reduction in protein content (proteinrestricted (PR) diet) during pregnancy show tissue-specific alterations in the expression of transcription factors which regulate a wide range of developmental and metabolic processes, specifically the glucocorticoid receptor (GR) (Bertram et al. 2001; Lillycrop et al. 2005) and peroxisomal proliferator-activated receptors (PPAR) (Burdge et al. 2004; Lillycrop

\footnotetext{
Abbreviations: ChIP, chromatin immunoprecipitation; Dnmt, DNA methyltansferase; GR, glucocorticiod receptor; HDAC, histone deacetylase; HMT, histone methyltransferase; MBD, methyl binding domain protein; MeCP2, methyl CpG-binding protein; PEPCK, phosphoenolpyruvate carboxykinase; PPAR, peroxisomal proliferator-activated receptor; PR, protein restricted; RT-PCR, reverse transcription-PCR; UC, umbilical cord.

* Corresponding author: Dr G. C. Burdge, fax +44 (0) 23 80594379, email g.c.burdge@ soton.ac.uk
} 
et al. 2005), and changes to the expression of genes associated with fatty acid metabolism (Maloney et al. 2003; Lillycrop et al. 2005) and carbohydrate homeostasis (Burns et al. 1997; Desai et al. 1997). Little is known about how information about the availability of nutrients in the extra-uterine environment is transmitted to the offspring or how different phenotypes are induced.

The methylation of $\mathrm{CpG}$ dinucleotides clustered at the $5^{\prime}$ promoter regions of genes established during early life confers stable silencing of transcription and is critical for cell differentiation (Bird, 2001). Following fertilisation, maternal and paternal genomes undergo extensive demethylation followed by de novo methylation by the activities of DNA methyltransferases (Dnmt) $3 \mathrm{a}$ and $3 \mathrm{~b}$ around the time of implantation (Bird, 2001; Reik et al. 2001). Patterns of DNA methylation are maintained through mitosis by Dnmt1 activity (Bird, 2001). Activities of Dnmt1 and Dnmt3a are modified by folic acid and homocysteine (James et al. 2002; Ghoshal et al. 2006). The timing of gene silencing during early development differs between genes and tissues (Grainger et al. 1983; Benvenisty et al. 1985; Gidekel \& Bergman, 2002; Hershko et al. 2003). In addition, the phenotype of an embryo can be modified by manipulation of Dnmt1 expression, and hence maintenance of patterns of DNA methylation (Stancheva \& Meehan, 2000; Stancheva et al. 2001; Biniszkiewicz et al. 2002).

DNA methylation can induce transcriptional silencing by blocking transcription factor binding and/or through the methyl CpG-binding protein $(\mathrm{MeCP} 2)$ that binds to methylated cytosines and which, in turn, recruits the histone deacetylase-histone methyltransferase (HDAC-HMT) complex to the DNA (Fuks et al. 2003). Covalent modifications to histones, such as acetylation and methylation of specific lysine residues in the N-terminal regions of histones, influence chromatin structure and hence the ability of the basal transcriptional machinery to gain access to the DNA (Strahl et al. 1999; Turner, 2000; Lachner et al. 2001; Litt et al. 2001; Nakayama et al. 2001; Zegerman et al. 2002).

Since epigenetic regulation of gene promoters which is established during development and is retained throughout the life span of the organism confers patterns of transcriptional expression and silencing, perturbations to such processes represent one possible molecular mechanism for induction of an altered phenotype. Feeding a PR diet to rats during pregnancy induces hypomethylation and increased expression of the GR and PPAR $\alpha$ promoters in the liver of the adult offspring (Lillycrop et al. 2005), but was prevented by supplementation of the PR diet with folic acid. Supplementation of the PR diet with glycine or folic acid prevented induction of an altered phenotype (Jackson et al. 2002; Torrens et al. 2006). Thus 1 -carbon metabolism is central to the induction of an altered phenotype in this model, which is consistent with the transient increase in plasma homocysteine, a marker of impaired 1-carbon metabolism, in early pregnancy when rats were fed a PR diet (Petrie et al. 2002).

We have tested the hypothesis that the transmission to the fetus of information regarding maternal nutrition and induction of altered DNA methylation involves modulation of Dnmt action. We investigated the effect of altered maternal protein intake during pregnancy on the epigenetic regulation of the hepatic GR promoter in the adult offspring. Specifically, we determined the effect of feeding a PR diet to pregnant rats on the methylation status and the level of histone modification at the hepatic GR promoter. In order to determine the mechanism which modifies the epigenetic regulation of the GR promoter, we investigated whether prenatal undernutrition alters the expression of enzymes that catalyse DNA methylation de novo, methylation of hemimethylated DNA or active demethylation of DNA. As a result of our findings, we also investigated the relationship between the expression of Dnmt and the methylation of the GR promoter that is expressed in human umbilical cord (UC).

\section{Materials and methods}

\section{Animal procedures}

Virgin Wistar rats (n 5 per dietary group) were fed isocaloric diets containing either $180 \mathrm{~g} / \mathrm{kg}$ casein and $1 \mathrm{mg} / \mathrm{kg}$ folic acid (control) or $90 \mathrm{~g} / \mathrm{kg}$ casein and $1 \mathrm{mg} / \mathrm{kg}$ folic acid (PR). In some experiments, livers from the offspring of rats fed $90 \mathrm{~g} /$ $\mathrm{kg}$ casein and $5 \mathrm{mg} / \mathrm{kg}$ folic acid were studied (Lillycrop et al. 2005) (Table 1). Dams were fed standard chow (AIN 76A) from delivery (Lillycrop et al. 2005). Litters were reduced to eight at birth, equal numbers of males and females, and offspring were weaned onto standard chow (AIN 76A) at $28 \mathrm{~d}$ and were killed $6 \mathrm{~d}$ later. Livers were excised immediately, frozen in liquid nitrogen and stored at $-80^{\circ} \mathrm{C}$. One liver from each litter was selected for analysis, male to female ratio 3:2. All animal procedures were conducted in accordance with the UK Home Office Animals (Scientific Procedures) Act (1986).

\section{Measurement of DNA methylation of the GRI 10 promoter in rat}

DNA methylation was carried out essentially as described (Lillycrop et al. 2005). Genomic DNA ( $5 \mathrm{mg}$ ) isolated from the livers of rats ( $n 5$ per maternal dietary group) was incubated with the methylation-sensitive restriction endonucleases Aci I and Hpa II, as instructed by the manufacturer (New England Biolabs, Hitchin, Hertfordshire, UK). The resulting DNA was amplified using real-time PCR, which was performed in a total volume of $25 \mathrm{ml}$ with $\mathrm{SYBR}^{\circledR}$ Green Jumpstart Ready Mix (Sigma, Poole, Dorset, UK) as described by the manufacturer. Cycle parameters were $55^{\circ} \mathrm{C}$ for $5 \mathrm{~min}, 95^{\circ} \mathrm{C}$ for $10 \mathrm{~min}$, then 40 cycles of $95^{\circ} \mathrm{C}$ for $30 \mathrm{~s}, 60^{\circ} \mathrm{C}$ for $1 \mathrm{~min}$ and $72^{\circ} \mathrm{C}$ for $1 \mathrm{~min}$. Single bands of the correct size were verified by gel electrophoresis. Primers were designed to amplify the $\mathrm{CpG}$ island spanning the $\mathrm{GR} 1_{10}$ promoter used in rat liver (McCormick et al. 2000). Primer sequences are listed in Table 2. The promoter region from the rat PPAR $\gamma 2$ promoter which does not contain Aci I or $H p a$ II cleavage sites was used as an internal control (Lillycrop et al. 2005). All $\mathrm{C}_{\mathrm{t}}$ values were normalised to the internal control and each sample analysed in duplicate.

\section{Measurement of $m R N A$ expression in rat}

Total RNA was isolated from liver ( $n 5$ per maternal dietary group) samples using $\operatorname{Tr}^{\circledR}{ }^{\circledR}$ Reagent (Sigma) according to the manufacturer's instructions. cDNA was prepared as described (Lillycrop et al. 2005) and amplified using real-time PCR 
Table 1. Composition of the diets fed during pregnancy, lactation and after weaning

\begin{tabular}{|c|c|c|c|c|}
\hline & \multicolumn{3}{|c|}{ Diets fed during pregnancy } & \multirow{2}{*}{$\begin{array}{l}\begin{array}{l}\text { Diet fed to dams during lactation } \\
\text { and to offspring after weaning }\end{array} \\
\text { AIN-76A }\end{array}$} \\
\hline & Control & Protein restricted & $\begin{array}{c}\text { Protein restricted, } \\
\text { supplemented with folic acid }\end{array}$ & \\
\hline Casein $(\mathrm{g} / \mathrm{kg})$ & 180 & 90 & 90 & 200 \\
\hline Folic acid (mg/kg) & 1 & 1 & 5 & 2 \\
\hline Cornstarch (g/kg) & 425 & 482 & 482 & 150 \\
\hline Sucrose $(\mathrm{g} / \mathrm{kg})$ & 213 & 243 & 243 & 500 \\
\hline Choline chloride $(\mathrm{g} / \mathrm{kg}$ ) & 2 & 2 & 2 & 2 \\
\hline DL-Methionine $(\mathrm{g} / \mathrm{kg})$ & 5 & 5 & 5 & 3 \\
\hline Vitamin mix $^{*}(\mathrm{~g} / \mathrm{kg})$ & 5 & 5 & 5 & 5 \\
\hline Mineral mix ${ }^{(\mathrm{g} / \mathrm{kg})}$ & 20 & 20 & 20 & 20 \\
\hline Cellulose $(\mathrm{g} / \mathrm{kg})$ & 50 & 50 & 50 & 50 \\
\hline Corn oil $(\mathrm{g} / \mathrm{kg})$ & 100 & 100 & 100 & 50 \\
\hline Total metabolisable energy $(\mathrm{MJ} / \mathrm{kg})$ & 20.2 & $19 \cdot 9$ & 19.9 & 15.5 \\
\hline
\end{tabular}

*Vitamin mix: thiamine hydrochloride $2.4 \mathrm{mg} / \mathrm{kg}$; riboflavin $2.4 \mathrm{mg} / \mathrm{kg}$; pyridoxine hydrochloride $2.8 \mathrm{mg} / \mathrm{kg}$; nicotinic acid $12.0 \mathrm{mg} / \mathrm{kg}$; D-calcium pantothenate $6.4 \mathrm{mg} / \mathrm{kg}$; biotin $0.01 \mathrm{mg} / \mathrm{kg}$; cyanocobalamin $0.003 \mathrm{mg} / \mathrm{kg}$; retinyl palmitate $6.4 \mathrm{mg} / \mathrm{kg} ; \mathrm{DL}-\alpha$-tocopherol acetate $79.9 \mathrm{mg} / \mathrm{kg}$; cholecalciferol $1.0 \mathrm{~g} / \mathrm{kg} ;$ menaquinone $0.02 \mathrm{mg} / \mathrm{kg}$.

† Mineral mix: calcium phosphate dibasic $11.3 \mathrm{~g} / \mathrm{kg}$; sodium chloride $1.7 \mathrm{~g} / \mathrm{kg}$; potassium citrate monohydrate $5.0 \mathrm{~g} / \mathrm{kg}$; potassium sulphate $1.2 \mathrm{~g} / \mathrm{kg}$; magnesium sulphate $0.5 \mathrm{~g} / \mathrm{kg}$; magnesium carbonate $0.1 \mathrm{~g} / \mathrm{kg}$; ferric citrate $0.1 \mathrm{~g} / \mathrm{kg}$; zinc carbonate $36.2 \mathrm{mg} / \mathrm{kg}$; cupric carbonate $6.8 \mathrm{mg} / \mathrm{kg}$; potassium iodate $0.2 \mathrm{mg} / \mathrm{kg}$; sodium selenite $0.2 \mathrm{mg} / \mathrm{kg}$; chromium potassium sulphate $12.5 \mathrm{mg} / \mathrm{kg}$.

(Harris et al. 2002) which was performed in a total volume of $25 \mathrm{ml}$ with $\mathrm{SYBR}^{\circledR}$ Green Jumpstart Ready Mix (Sigma) as described by the manufacturer. PCR primers are listed in Table 2. Samples were analysed in duplicate, and the expression of $\mathrm{GR} 1_{10}$ promoter transcript, Dnmt1, Dnmt3a, Dnmt3b, MeCP2 and methyl binding domain protein-2 (MBD-2) was normalised to the housekeeping gene cyclophilin (Bustin, 2000). Dnmt1, 3a and 3b were measured using primer kits from QIAGEN Ltd UK (Crawley, Sussex, UK). Cycle parameters were $55^{\circ} \mathrm{C}$ for $5 \mathrm{~min}, 95^{\circ} \mathrm{C}$ for $10 \mathrm{~min}$, then 40 cycles of $95^{\circ} \mathrm{C}$ for $30 \mathrm{~s}, 60^{\circ} \mathrm{C}$ (cyclophilin, phoephoenolpyruvate carboxykinase (PEPCK), Dnmt1, Dnmt 3a, Dnmt3b, MeCP2 and MBD2) or $65^{\circ} \mathrm{C}$ (GR) for $1 \mathrm{~min}$ and $72^{\circ} \mathrm{C}$ for $1 \mathrm{~min}$. Single bands of the correct size were verified by gel electrophoresis (data not shown).

\section{Measurement of histone acetylation and methylation at the GR promoter in rat}

Histone modification, and MeCP2 and Dnmt1 binding at the GR $1_{10}$ promoter was analysed by chromatin immunoprecipitation
(ChIP) assay (Boyd \& Farnham, 1999). A $100 \mathrm{mg}$ aliquot of liver tissue ( $n 5$ per maternal dietary group, one per litter) was ground in liquid nitrogen and fixed with formaldehyde $(1 \%(\mathrm{v} / \mathrm{v}))$ for $10 \mathrm{~min}$. The chromatin was sonicated to yield DNA fragments of 100-400 bp in length. The sonicated chromatin was quantified on the basis of DNA content at $A_{260 \mathrm{~nm}}$. The chromatin equivalent of $40 \mu \mathrm{g}$ of DNA was used in each immunoprecipitation. The sonicated supernatant was diluted 10-fold in ChIP dilution buffer (0.01\% (w/v) SDS, $1.1 \%(\mathrm{v} / \mathrm{v})$ Triton X-100, $1.2 \mathrm{~mm}-$ EDTA, 16.7 mM-NaCl, $20 \mathrm{~mm}$-Tris- $\mathrm{HCl} \mathrm{pH} 8.1)$ and pre-cleared with salmon sperm DNA-protein A agarose (50\% (w/v) slurry). Pre-cleared chromatin was then incubated overnight with $2 \mathrm{mg}$ of antibody at $4{ }^{\circ} \mathrm{C}$. Anti- $\beta$-galactosidase (c-20) antibodies were obtained from Santa Cruz Biotechnology Inc. (Santa Cruz, CA, USA). Anti-acetyl histone H3 (06-599), anti-acetyl H4 (06-866), di-methylated H3K4 (07-030), di-methylated H3K9 (07-441) were from Upstate Biotechnology (Dundee, UK) and tri-methylated H3K9 (ab8898), Dnmt1 (ab5208) and MeCP2 (ab3752) were from Abcam (Cambridge, UK). The immunocomplexes were collected by the addition of salmon sperm DNA-protein A agarose slurry, washed with $0.1 \%(\mathrm{w} / \mathrm{v})$ SDS, $1 \%(\mathrm{v} / \mathrm{v})$

Table 2. PCR primers for analysis of mRNA expression and promoter methylation

\begin{tabular}{|c|c|c|}
\hline Gene & Forward primer & Reverse primer \\
\hline \multicolumn{3}{|c|}{ Methylation-sensitive PCR } \\
\hline $\mathrm{GR} 1_{10}$ & TCCTCCATTTTTTGCGAGCTC & CCACCGCAGCCAGATAAAC \\
\hline PPAR $-\gamma_{2}$ & GTCTCTGCTCTGGTAATTC & AAGGCTTGTGGTCATTGAG \\
\hline hGR1-C & ATTTTGCGAGCTCGTGTCTG & CGCAGCCGAGATAAACAACT \\
\hline hPPAR- $\alpha$ & CGGAGTTTATGAGGCCATATTC & AGGGAGATATCACTGTCATCCAG \\
\hline \multicolumn{3}{|c|}{ mRNA expression } \\
\hline GR & TGACTTCCTTCTCCGTGACA & GGAGAATCCTCTGCTGCTTG \\
\hline Dnmt1 & QIAGEN Quantitect ${ }^{\circledR}$ primer assay QT00493577 & \\
\hline Dnmt3a & QIAGEN Quantitect ${ }^{\circledR}$ primer assay QT00429380 & \\
\hline Dnmt3b & QIAGEN Quantitect ${ }^{\circledR}$ primer assay QT00436002 & \\
\hline MeCP2 & CAGCTCCAACAGGATTCCATGGT & TGATGTCTCTGCTTTGCCTGCCT \\
\hline MDB2 & GGCAAGAGCGATGTCTACTA & CTGGACCGACTCCTTGAAGA \\
\hline Cyclophilin & TTGGGTCGCGTCTGCTTCGA & GCCAGGACCTGTATGCTTCA \\
\hline hGR1-C $\mathrm{C}_{\text {Total }}$ & GCTCCTCTGCCAGAGTTGAT & CAGTGGATGCTGAACTCTTGG \\
\hline
\end{tabular}


Triton X-100, 2 mm-EDTA, Tris-HCl pH 8.1, 150 mm-NaCl, Tris $-\mathrm{HCl} \mathrm{pH} 8 \cdot 1$ and then with $0.1 \%(\mathrm{w} / \mathrm{v})$ SDS, $1 \%(\mathrm{v} / \mathrm{v})$ Triton X-100, 2 mm-EDTA, $500 \mathrm{~mm}-\mathrm{NaCl}, 20 \mathrm{~mm}-\mathrm{Tris}-\mathrm{HCl}$ $\mathrm{pH} 8.1$ followed by $0.25 \mathrm{M}-\mathrm{LiCl}, 1 \%(\mathrm{v} / \mathrm{v}) \mathrm{NP}-40,1 \%(\mathrm{w} / \mathrm{v})$ sodium deoxycholate, $1 \mathrm{~mm}-\mathrm{EDTA}, 10 \mathrm{~mm}-\mathrm{Tris}-\mathrm{HCl} \mathrm{pH} 8 \cdot 1$ and twice with $10 \mathrm{~mm}$-Tris- $\mathrm{HCl} \mathrm{pH} 7 \cdot 5,1 \mathrm{~mm}$-EDTA). DNA was eluted by the addition of a solution of $1 \%(\mathrm{w} / \mathrm{v})$ SDS and $0 \cdot 1 \mathrm{M}-\mathrm{NaHCO}_{3}$, the cross-links reversed, and the DNA purified. The ChIP-precipitated DNA and the input DNA were subjected to real-time PCR using SYBR ${ }^{\circledR}$ Green Jumpstart Ready Mix (Sigma). The PCR primers used for the $\mathrm{GR} 1_{10}$ promoter were 5'-CGTCTTGTTCCACCCACT-3' and 5'-CCTTGCAGTTGCCGACAG. All values were normalised with respect to the input DNA and expressed as a percentage of the control group. To demonstrate the specificity of the immunoprecipitation reactions, an antibody directed against $\beta$-galactosidase and a negative antibody control were used in each experiment (data not shown).

\section{Human umbilical cord samples}

These studies utilised samples of UC from a stratified random sample of fifteen term infants in the Birthright Fetal Growth Rates Study. This study of nutrition during pregnancy and fetal growth recruited Caucasian women with singleton pregnancies and known menstrual dates who registered in early pregnancy with participating obstetricians at the Princess Anne Maternity Hospital, Southampton UK (Godfrey et al. 2001). Samples were stored at $-80^{\circ} \mathrm{C}$. Birthweights of the infants were in the normal range (range 2665-4430 $\mathrm{g}$, mean $3426 \mathrm{~g}$ ). Collection and analysis of human UC samples was carried out with written informed consent from all subjects and under IRB approval from the Southampton and South West Hampshire Joint Research Ethics Committee.

\section{DNA methyltransferase mRNA expression in human umbilical cord}

Total RNA was isolated from human UC using Tri ${ }^{\circledR}$ Reagent (Sigma, Poole, Dorset, UK) according to the manufacturer's instructions. cDNA was prepared as described (Lillycrop et al. 2005) and amplified using real-time reverse transcription-PCR (RT-PCR), which was performed in a total volume of $25 \mathrm{ml}$ with SYBR ${ }^{\circledR}$ Green Jumpstart Ready Mix (Sigma) as described by the manufacturer. Human Dnmt1 shows $80 \%$ identity to rat Dnmt1, and human Dnmt3a shows $91 \%$ identity to rat Dnmt3a. There was $100 \%$ identity between rat and human Dnmt1 and between rat and human Dnmt3a within the primer sequences. Therefore, we used the same RT-PCR primers to measure Dnmt1 and Dnmt3a expression in human UC and rat liver. PCR primers are listed in Table 2. Samples were analysed in duplicate and the expression of Dnmt1 and Dnmt3a was normalised to the housekeeping gene cyclophilin (Bustin, 2000). Cycle parameters were $94^{\circ} \mathrm{C}$ for $2 \mathrm{~min}$, then 40 cycles of $95^{\circ} \mathrm{C}$ for $30 \mathrm{~s}, 60^{\circ} \mathrm{C}$ (cyclophilin and Dnmt 1 ) or $62^{\circ} \mathrm{C}$ (Dnmt3a) for $1 \mathrm{~min}$ and $72^{\circ} \mathrm{C}$ for $1 \mathrm{~min}$.

\section{Measurement of DNA methylation of the GR1-C $C_{\text {Total }}$ promoter in human umbilical cord}

To confirm that the GR1- $\mathrm{C}_{\text {Total }}$ promoter is expressed in human UC, total RNA was isolated from UC and human blood using Tri ${ }^{\circledR}$ Reagent (Sigma) as described by the manufacturers. The size of the GR1-C $\mathrm{C}_{\text {Total }}$ promoter RT-PCR transcript from UC on agarose gel electrophoresis was compared with the blood reference transcript (Turner \& Muller, 2005) (Fig. 2A). PCR primers are listed in Table 2. Cycle parameters were $94^{\circ} \mathrm{C}$ for $2 \mathrm{~min}$, then 40 cycles of $95^{\circ} \mathrm{C}$ for $30 \mathrm{~s}, 62^{\circ} \mathrm{C}$ for $1 \mathrm{~min}$ and $72^{\circ} \mathrm{C}$ for $1 \mathrm{~min}$.

For analysis of GR1- $\mathrm{C}_{\text {Total }}$ promoter methylation, genomic DNA (400 ng) was incubated with the methylation-sensitive restriction endonucleases $A c i \mathrm{I}$ and $H p a$ II as instructed by the manufacturer (New England Biolabs, Hitchin, Hertfordshire, UK). The resulting DNA was amplified using realtime PCR, which was performed in a total volume of $25 \mathrm{ml}$ with SYBR ${ }^{\circledR}$ Green Jumpstart Ready Mix (Sigma) according to the manufacturer's instructions. A fragment of the human PPAR $\alpha$ exon 7 which does not contain Aci I or Hpa II cleavage sites was used as an internal control gene. Primers were designed to amplify the $\mathrm{CpG}$ island spanning the

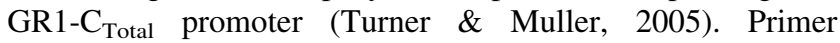
sequences are listed in Table 2. Cycle parameters were $94^{\circ} \mathrm{C}$ for $2 \mathrm{~min}$, then 40 cycles of $95^{\circ} \mathrm{C}$ for $30 \mathrm{~s}, 59.3^{\circ} \mathrm{C}$ $\left(\mathrm{GR} 1-\mathrm{C}_{\text {Total }}\right)$ or $66^{\circ} \mathrm{C}(\mathrm{PPAR} \alpha)$ for $1 \mathrm{~min}$ and $72^{\circ} \mathrm{C}$ for $1 \mathrm{~min}$. All $\mathrm{C}_{\mathrm{t}}$ values were normalised to the internal control and each sample analysed in duplicate. Single bands of the correct size were verified by gel electrophoresis (not shown).

\section{Statistical analysis}

Data are presented as mean (SEM). Statistical comparisons were by Student's unpaired $t$ test or one-way ANOVA with Bonferroni's post hoc analysis as indicated in the text. The relationship between DNA methylation and gene expression in human UC was determined by calculation of Pearson's correlation coefficient.

\section{Results}

GR promoter methylation, and expression of GR and PEPCK in rat liver

Hepatic GR $1_{10}$ promoter methylation was $33 \%$ lower (Table 3) at postnatal day 34 in the offspring of dams fed a PR diet compared with offspring of the control group. Hypomethylation of the $\mathrm{GR} 1_{10}$ promoter was associated with higher mRNA expression of GR $1_{10}(84 \%)$. The expression of the GR target gene PEPCK was also increased by $16 \%$ in the offspring of the PR group (Table 3).

\section{$\mathrm{MeCP} 2$ expression in rat liver}

Having shown GR hypomethylation in PR offspring, we then investigated whether the expression and recruitment of $\mathrm{MeCP} 2$ to the $\mathrm{GR} 1_{10}$ promoter was also altered in response to maternal diet. MeCP2 mRNA expression was $29 \%$ lower in the liver of the PR offspring versus controls (Table 4). Binding of MeCP2 to the GR promoter in the liver of control and PR offspring was assessed using a ChIP assay. Binding of $\mathrm{MeCP} 2$ to the $\mathrm{GR} 1_{10}$ promoter was reduced by $43 \%$ $(P<0.05)$ in $\mathrm{PR}$ offspring compared with control offspring (Table 4). No signal was obtained when chromatin was preci- 
Table 3. Glucocorticoid receptor promoter methylation, and glucocorticoid receptor and phosphoenolpyruvate carboxykinase mRNA expression in the liver of day 34 offspring

(Mean values with their standard errors of the mean)

\begin{tabular}{lrrrrrr}
\hline & \multicolumn{4}{l}{ Relative to the control group (\%) } \\
\cline { 2 - 3 } & \multicolumn{2}{c}{ Control } & & \multicolumn{2}{c}{ PR } & \\
\cline { 2 - 3 } & Mean & SEM & & Mean & SEM & $P$ \\
\hline GR1 $_{10}$ methylation & 100.0 & 3.5 & 67.3 & 1.5 & $<0.001$ \\
GR1 10 mRNA expression & 100.0 & 22.0 & 184.0 & 11.0 & $<0.05$ \\
PEPCK mRNA expression & 100.0 & 2.3 & 116.0 & 4.0 & $<0.05$ \\
\hline
\end{tabular}

PR, protein-restricted; GR $1_{10}$, glucocorticoid receptor $1_{10}$ promoter; PEPCK, phosphoenolpyruvate carboxykinase.

Values are the results of RT-PCR analysis for $n 5$ samples/maternal dietary group. Statistical comparison was by Student's unpaired $t$ test.

pitated with an anti- $\beta$-galactosidase antibody or with a negative antibody control. This demonstrates that the immunoprecipitation reactions were specific.

\section{Analysis of histone modifications at the hepatic $G R 1_{10}$ promoter in rats}

In order to determine whether the hypomethylation of the GR $1_{10}$ promoter, and reduced expression and binding of MeCP2 were associated with altered covalent modifications of histones bound to the GR promoter, ChIP assays were used to measure the acetylation and methylation of specific histone lysine residues at the GR $1_{10}$ promoter. The level of histone modifications which facilitate transcription was higher at the hepatic $\mathrm{GR} 1_{10}$ promoter in the PR versus control offspring, namely acetylation of $\mathrm{H} 3 \mathrm{~K} 9(174 \%)$ and $\mathrm{H} 4 \mathrm{~K} 9$ (302\%), and methylation of H3K4 (925\%) (all $P<0.001)$ (Table 4). Di-methylation and tri-methylation of $\mathrm{H} 3 \mathrm{~K} 9$, which are associated with suppression of transcription, were $54 \%$ lower $(P<0 \cdot 01)$ or not statistically significantly

Table 4. MeCP2 mRNA expression, binding of MeCP2 and histone modifications at the glucocorticoid receptor promoter

(Mean values with their standard error of the mean)

\begin{tabular}{|c|c|c|c|c|c|}
\hline & \multicolumn{4}{|c|}{ Relative to the control group (\%) } & \multirow[b]{3}{*}{$P$} \\
\hline & \multicolumn{2}{|c|}{ Control } & \multicolumn{2}{|c|}{ PR } & \\
\hline & Mean & SEM & Mean & SEM & \\
\hline MeCP2 mRNA expression & $100 \cdot 0$ & 9.3 & 71.4 & 7.3 & $<0.05$ \\
\hline MeCP2 binding & 100 & 2 & 57 & 2 & $<0.05$ \\
\hline \multicolumn{6}{|l|}{ Histone modifications } \\
\hline H3K9 acetylation & 100 & 12 & 274 & 20 & $<0.0001$ \\
\hline H4K9 acetylation & 100 & 18 & 402 & 33 & $<0.0001$ \\
\hline H3K9 methylation & 100 & 20 & 1025 & 87 & $<0.0001$ \\
\hline H3K9 dimethylation & 100 & 22 & 19 & 16 & $<0.001$ \\
\hline H3K9 trimethylation & 100 & 60 & 103 & 11 & NS \\
\hline
\end{tabular}

MeCP2, methyl CpG-binding protein; PR, protein-restricted.

Values are for $n 5$ samples/maternal dietary group. Statistical comparison was by Student's unpaired $t$ test. Expression of MeCP2 and binding of MeCP2 at the glucocorticoid receptor $1_{10}\left(\mathrm{GR} 1_{10}\right)$ promoter in liver from 34-day-old offspring of rats fed either a control or PR diet during pregnancy. Binding of MeCP2 and the extent of histone modifications at the $\mathrm{GR} 1_{10}$ promoter were determined by chromatin immunoprecipitation assay. different, respectively, in the PR offspring versus controls at the $\mathrm{GR} 1_{10}$ promoter (Table 4 ).

\section{Analysis of the expression of genes which regulate DNA methylation in the liver of rats}

There are three possible mechanisms underlying hypomethylation of the GR $1_{10}$ promoter: (1) impaired methylation de novo by Dnmt 3a and 3b; (2) failure to maintain CpG methylation through mitosis by Dnmt1; or (3) active demethylation by the putative DNA demethylase MBD2 (Detich et al. 2002). To examine which of these mechanisms may be responsible for the hypomethylation of GR, the expression of Dnmt1, Dnmt $3 \mathrm{a} / \mathrm{b}$ and the demethylase MBD2 was measured using real-time RT-PCR. Expression of Dnmt1 mRNA was $17 \%$ lower $(P<0.05)$ in $\mathrm{PR}$ versus control offspring (Fig. 1A). There were no significant differences between $P R$ and control offspring in the expression of Dnmt $3 \mathrm{a}$ and $3 \mathrm{~b}$, or MBD2 (Fig. 1B-D). ChIP assays using an anti-Dnmt1 antibody showed that binding of Dnmt 1 at the $\mathrm{GR} 1_{10}$ promoter was significantly lower $(12 \%, P<0.05)$ in the PR offspring compared with controls (Fig. 1E).

Since 1-carbon metabolism appears to be involved centrally for the induction of an altered phenotype by variations in maternal protein intake during pregnancy (Petrie et al. 2002; Torrens et al. 2006), and hypomethylation of the hepatic GR is prevented by supplementation of the PR diet with folic acid (Lillycrop et al. 2005), we next investigated the effect of supplementation of the PR diet with 5-fold more folic acid than was present in the control or PR diet. Supplementing the PR diet with folic acid prevented reduced Dnmt1 expression compared with the control group (Fig. 1A), but did not alter Dnmt 3a or 3b expression (Fig. 1B, C).

\section{Analysis of GR promoter methylation and Dnmt1 expression in human umbilical cord}

Since Dnmt1 mRNA expression appeared to be related to the level of methylation of the hepatic GR promoter, we investigated whether Dnmt1 expression was also related to the level of GR methylation in fetal human tissue. The human GR1-C $\mathrm{C}_{\text {Total }}$ promoter, like the rat $\mathrm{GR} 1_{10}$ promoter, contains a $\mathrm{CpG}$ island which spans the $5^{\prime}$-untranslated region of the gene and which contains eleven different heterogeneous non-coding first exons (Turner \& Muller, 2005). In the human fetal UC samples, we examined the methylation status of the GR1-C $\mathrm{C}_{\text {Total }}$ promoter, which shows $70.6 \%$ homology with the rat GR1 $1_{10}$ promoter (Turner \& Muller, 2005). We showed that transcripts from the GR1- $\mathrm{C}_{\text {Total }}$ promoter are expressed in human UC (Fig. 2A). Using a methylationsensitive restriction enzyme PCR assay, we found that there was variation in the level of methylation of the GR1- $\mathrm{C}_{\text {total }}$ promoter between human fetal cord samples such that the highest level of methylation was approximately 2 -fold greater than the lowest (Fig. 2D).

Single bands of the correct size for the PCR products of the Dnmt1 and Dnmt3a primers in human and rat tissue were verified by gel electrophoresis (Fig. 2B, C). Dnmt1 expression predicted $49 \%(P=0.003)$ of the variation in GR1-C $\mathrm{C}_{\text {Total }}$ methylation (Fig. 2D), while Dnmt3a expression was not related to GR1-C $\mathrm{C}_{\text {Total }}$ methylation (Fig. 2E). 

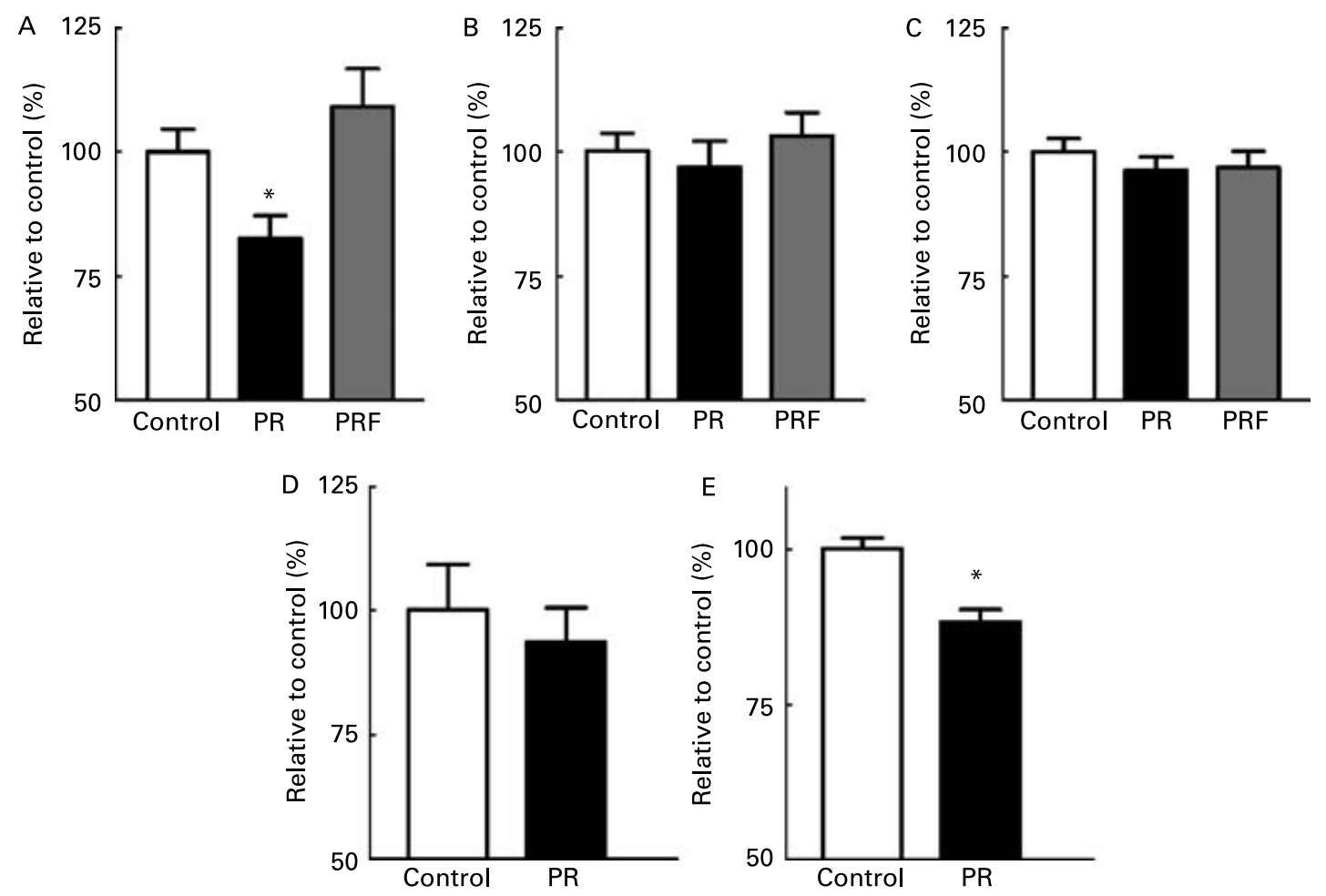

Fig. 1. mRNA expression of DNA methyltransferases (Dnmt) in liver from 34-day-old offspring of rats fed either a control or protein-restricted (PR) diet, or the PR diet supplemented with folic acid (PRF) during pregnancy. Data from RT-PCR analysis are means (with SEM) relative to the control group ( $n 5$ per maternal dietary group). (A) Dnmt1 expression. (B) Dnmt3a expression. (C) Dnmt3b expression. Statistical comparisons were by one-way ANOVA with Bonferroni's post hoc analysis. One-way ANOVA showed a significant difference $(P<0.05)$ between groups for Dnmt1, but not for the other DNA methyltransferases. ${ }^{\star} P<0.05$ compared with the control group. (D) Expression of the methyl binding domain protein-2 from 34-day-old offspring of rats fed either a control or PR diet. Data are means (with SEM) relative to the control group ( $n 5$ per maternal dietary group). Statistical analysis was by Student's unpaired $t$ test. (E) Binding of Dnmt1 at the glucocorticoid receptor $1_{10}$ promoter in liver from 34-day-old offspring of rats fed either a control or PR diet measured by chromatin immunoprecipitation assay. Data are means (with SEM) relative to the control group ( $n 5$ per maternal dietary group). Statistical analysis was by Student's unpaired $t$ test. ${ }^{\star} P<0.05$ compared with the control group.

A

B

C
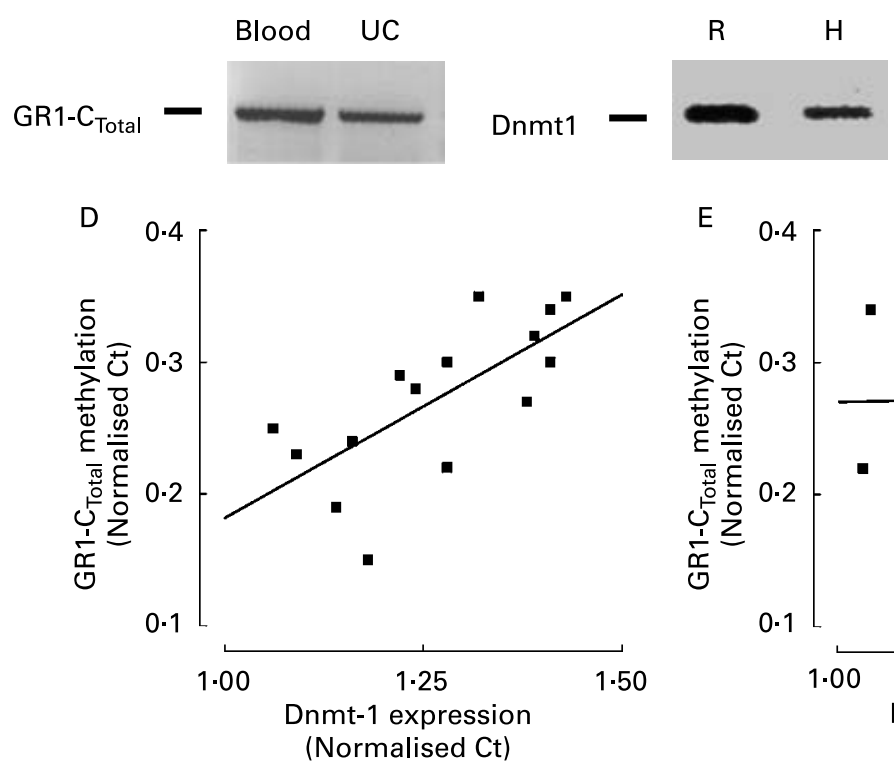

$\mathrm{H}$

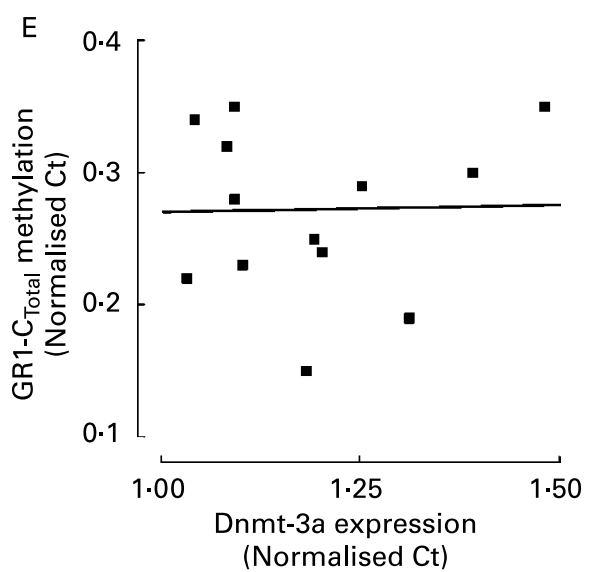

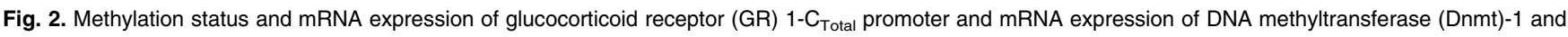
Dnmt3a in human umbilical cord (UC). (A) Expression of the transcript of the GR1-C Total $_{\text {in }}$ human UC by real-time RT-PCR using adult human blood as reference. The same primers were used to detect $(B)$ Dnmt1 and $(C)$ Dnmt3a in human $(H)$ UC as used with rat $(R)$ liver. Transcripts of the appropriate size were identified by analysis of the RT-PCR products by agarose gel electrophoresis. The methylation status of the GR1- $\mathrm{C}_{\text {Total }}$ promoter and the mRNA expression of Dnmt1 and Dnmt3a were measured in human UC samples from fifteen pregnancies. The association between $\mathrm{GR} 1-\mathrm{C}_{\text {Total }}$ promoter methylation and Dnmt expression was analysed by calculation of Pearson's correlation coefficient. (D) The relationship between Dnmt1 expression and GR1-C $\mathrm{C}_{\text {Total }}$ promoter methylation, $r=0 \cdot 70$, $P=0.03$. (E) The relationship between Dnmt3a expression and GR1- $\mathrm{C}_{\text {Total }}$ promoter methylation, $r=0.001, P=0.89$ ). 


\section{Discussion}

The results of this study show for the first time that hypomethylation and increased expression of the GR $1_{10}$ promoter induced in the liver of the offspring of rats fed a PR diet during pregnancy are associated with reduced Dnmt1 expression and altered covalent modifications to histones at the GR promoter.

Feeding a PR diet to pregnant rats increases hepatic gluconeogenesis in the adult offspring (Burns et al. 1997; Desai et al. 1997), which reflects increased expression of hepatic GR and PEPCK expression (Bertram et al. 2001, Lillycrop et al. 2005). This is consistent with increased corticosteroid activity in the offspring of rats fed a PR diet during pregnancy (Langley-Evans et al. 1996). Our current and previous findings (Lillycrop et al. 2005) show that increased hepatic GR expression in the PR offspring is associated with hypomethylation of the $\mathrm{GR} 1_{10}$ promoter. The livers of these rats also show hypomethylation of the PPAR $\alpha$ promoter and increased expression of its target gene acyl-CoA oxidase (Lillycrop et al. 2005). Together, these findings suggest that feeding a PR diet during pregnancy induces in the liver of the offspring a metabolic phenotype characterised by altered regulation of energy balance, with increased capacity for gluconeogenesis and peroxisomal fatty acid $\beta$-oxidation. Moreover, since promoter methylation status may be modified at different stages of development in a gene- and tissue-specific manner (Grainger et al. 1983; Benvenisty et al. 1985; Gidekel \& Bergman, 2002; Hershko et al. 2003), this suggests a mechanism by which timing of nutritional constraint may influence the induced phenotype (Ravelli et al. 1998; Remacle et al. 2004).

The stable silencing of genes by DNA methylation is critical for cellular differentiation (Bird, 2001; Hershko et al. 2003) and for the developmental regulation of the activities of metabolic pathways (Grainger et al. 1983; Benvenisty et al. 1985). Induction of hypomethylation of the hepatic GR promoter in the PR offspring may occur by either impaired methylation de novo during cell differentiation in the early embryo, failure to maintain DNA methylation during mitosis or active demethylation. Failure to maintain methylation or active demethylation may result in the activation of genes not normally expressed in adult tissues, or accelerated or more extensive demethylation of genes that are induced during tissue maturation. Our findings show that, while the expression of Dnmt3a and $3 b$ and the demethylase MDB2 was not altered, Dnmt1 expression was significantly lower in the liver of the PR offspring compared with controls. Thus hypomethylation of the $\mathrm{GR} 1_{10}$ promoter, and in turn altered regulation of hepatic glucose metabolism, may be induced by reduced capacity to methylate hemimethylated DNA during mitosis rather than failure of DNA methylation de novo or active demethylation. This conclusion is supported by lower binding of Dnmt 1 at the $\mathrm{GR} 1_{10}$ promoter in the PR offspring. These findings agree with those showing induction of DNA hypomethylation and altered phenotype by depletion of xDnmt1 in Xenopus embryos (Stancheva \& Meehan, 2000; Stancheva et al. 2001) and promoter demethylation by Dnmt1 knockdown (Leu et al. 2003).

Altered 1-carbon metabolism plays a central role in phenotype induction in this model (Jackson et al. 2002; Petrie et al. 2002; Lillycrop et al. 2005; Torrens et al. 2006). Our findings show that lowering of Dnmt1 expression by the PR diet was prevented by maternal folic acid supplementation, while expression of Dnmt3a was unaltered. Hence Dnmt1 expression in the offspring is modified by maternal folic acid intake, which is consistent with the modulation of Dnmt1 expression in adult rats by folic acid intake (Ghoshal et al. 2006) and the inhibition of Dnmt1 and induction of DNA hypomethylation by hyperhomocysteinaemia (James et al. 2002). Thus, the effects of differences in maternal folic acid intake, and in turn capacity for metabolism of methyl groups, during pregnancy could explain the induction or prevention of GR $1_{10}$ hypomethylation in the liver of the offspring. These findings also emphasise the importance of adequate dietary intake of folic acid during pregnancy for optimal fetal development.

One possible mechanism for induction of an altered metabolic phenotype in the liver of the offspring of rats fed a PR diet during pregnancy is impairment of 1-carbon metabolism leading to down-regulation of Dnmt1 expression and progressive loss of methyl groups from the GR $1_{10}$ promoter. Reduced expression of Dnmt1 may be expected to result in decreased methylation of all promoters containing $\mathrm{CpG}$ dinucleotides. However, studies in cells lacking Dnmt1 show only a $20 \%$ decrease in genomic methylation and no changes to the methylation status of specific genes (Rhee et al. 2000). This suggests that Dnmt1 activity is targeted to specific genes, possibly through binding to transcription factors such as $\mathrm{E}_{2} \mathrm{~F} 1$ (Robertson et al. 2000). Thus because binding of Dnmt1 to the GR promoter was reduced in addition to an overall reduction in Dnmtl expression, the proposed pathway is consistent with gene-specific hypomethylation in the liver in the offspring of dams fed a PR diet (Lillycrop et al. 2005). Dnmt1 activity is also required for progression through mitosis (Milutinovic et al. 2003). Thus it is possible that suppression of Dnmt1 activity or expression by altered 1-carbon metabolism in the pre-implantation period could also account for the reduction in cell number during the early development in this model (Kwong et al. 2000).

The specific link between reduced protein intake and altered 1-carbon metabolism cannot be deduced from the present data. However, we offer two possible explanations. First, it is possible that it may result from decreased availability of glycine, leading to altered flux of methyl groups between different metabolic fates. Secondly, increased maternal corticosteroid activity (Langley-Evans et al. 1996), possibly as a result of stress induced by constrained nutrient availability, may reduce folic acid availability (Terzolo et al. 2004). The second mechanism could explain how maternal corticosteroid blockade prevents induction of hypertension in the PR offspring (Langley-Evans et al. 1997) as well as prevention of altered phenotype by folic acid administration (Lillycrop et al. 2005; Torrens et al. 2006).

Analysis of GR1- $\mathrm{C}_{\text {Total }}$ in human UC samples showed for the first time that among individuals within the normal birthweight range, there is considerable variation in the methylation status of a gene expressed in human fetal tissue. Dnmt 1 expression predicted $49 \%$ of the variation in methylation of the GR1- $\mathrm{C}_{\text {Total }}$ promoter expressed in human UC. Because the UC were frozen, we were unable to dissect and measure Dnmt1 expression and GR1- $\mathrm{C}_{\text {Total }}$ methylation in specific tissues. However, these data suggest that methylation of the GR1-C $\mathrm{C}_{\text {Total }}$ promoter in human UC is associated with 
the capacity of Dnmt1 to maintain methylation of $\mathrm{CpG}$ dinucleotides rather than the capacity for DNA methylation de novo. The extent to which maternal diet during pregnancy determines Dnmt1 expression cannot be examined within this small group of infants. However, these findings are consistent with our observations in the rat and so suggest the hypothesis that induction of different phenotypes in humans by prenatal nutrition may involve variations in Dnmt1 expression and, in turn, DNA methylation.

Covalent modifications of specific residues in the N-terminal domain of histones also confer epigenetic regulation of transcription (Turner, 2000). Such modifications are closely linked to promoter methylation as methylated $\mathrm{CpG}$ nucleotides are required for binding of $\mathrm{MeCP} 2$ and recruitment of the HDAC-HMT complex. Binding of MeCP2-HDACHMT to methylated $\mathrm{CpGs}$ causes histone deacetylation and methylation of specific lysine resides, leading to suppression of transcription. We found higher levels of histone modifications which facilitate transcription, while modifications that suppress transcription were reduced, at the GR $1_{10}$ promoter in the offspring of rats fed the PR diet compared with controls. One possible explanation is that hypomethylation of the $\mathrm{GR} 1_{10}$ promoter reduced binding of $\mathrm{MeCP} 2$ and, in turn, the HDAC-HMT complex. If so, this suggests that lower
Dnmt 1 expression is the primary process in inducing increased GR $1_{10}$ expression, and altered histone modifications are a secondary effect. This may be exacerbated by lower hepatic $\mathrm{MeCP} 2$ expression in these offspring. Such changes to the regulation of transcription of the $\mathrm{GR} 1_{10}$ promoter are consistent with the higher level of transcription in the PR offspring.

We therefore propose a mechanism for the induction of an altered metabolic phenotype in the offspring of rats fed a PR diet during pregnancy based upon our findings for the $\mathrm{GR} 1_{10}$ promoter (Fig. 3). Promoter methylation is induced in a genespecific manner during the development of the early embryo by the activities of Dnmt 3a and 3b. Impaired 1-carbon metabolism, either as a direct result of constrained maternal nutrition or by increased corticosteroid activity, reduces Dnmt1 expression, resulting in progressive hypomethylation of specific genes during successive mitotic cycles. The hypomethylated $\mathrm{GR} 1_{10}$ promoter would result in the reduced binding of the MeCP2-HDAC-HMT complex which facilitates persistence of histone modifications that permit transcription. In turn, gluconeogenesis increases due to upregulation of PEPCK expression by the action of the GR. The pathway may also explain hypomethylation of PPAR $\alpha$ and increased expression of acyl-CoA oxidase in the liver of the PR offspring (Lillycrop et al. 2005). If this pathway acts primarily

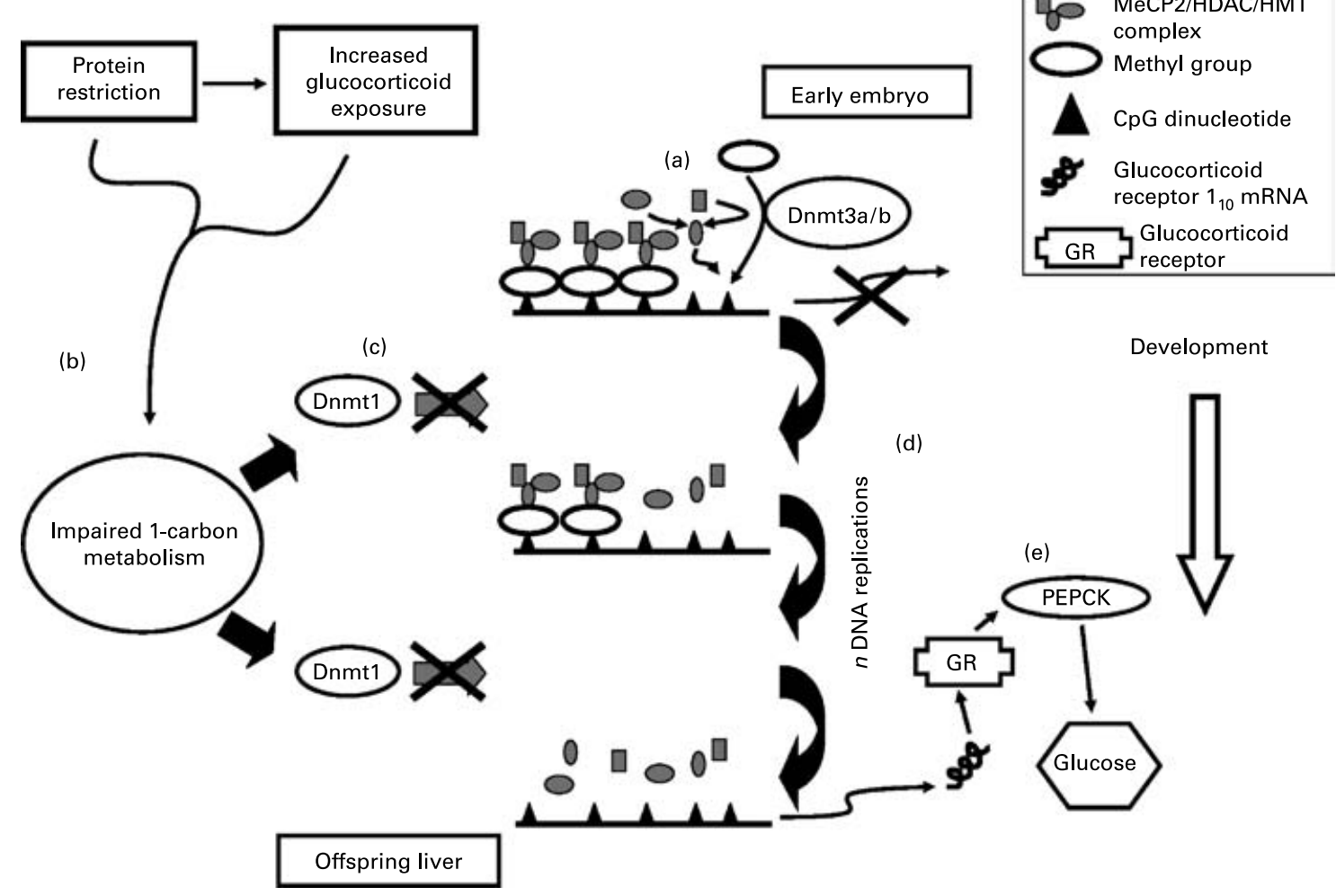

Fig. 3. A diagram of the proposed pathway for induction of altered glucose homeostasis in the offspring of rats fed a protein-restricted (PR) diet during pregnancy. A full explanation is given in the text. (a) Glucocorticoid receptor (GR) expression is silenced in the early embryo in cells destined to become hepatocytes by the activities of DNA methyltransferases (Dnmt) 3a and 3b. (b) In the offspring of rats fed a PR diet, 1-carbon metabolism is impaired either as a direct consequence of the restricted diet or by increased glucocorticoid exposure. This downregulates Dnmt1 expression (c). Lower Dnmt1 expression results in a impaired capacity to methylate hemimethylated DNA during mitosis (d). After sequential mitotic cycles, this results in hypomethylation of the GR promoter and loss of epigenetic memory of gene silencing, such that, in the liver of the adult offspring, expression of GR is induced in cells which do not express GR in control animals. The increased expression of GR is facilitated by lower binding and expression of methyl CpG-binding protein (MeCP)-2 and reduced recruitment of the histone deactylase (HDAC)-histone methyltransferase (HMT) complex, resulting in higher levels of histone modifications which permit transcription. (e) This results in increased phosphoenolpyruvate carboxykinase (PEPCK) expression and increased gluconeogenesis. 
by altering the epigenetic regulation of specific transcription factors, then changes in the activities of a number of metabolic pathways may be induced. However, the proposed pathway does not exclude the possibility that other genes may also be hypomethylated by this process. This pathway also explains how administration of glucocorticoids during pregnancy induces persistent changes to gluconeogenic enzymes in the offspring as a result of increasing GR expression (Nyirenda et al. 1998).

In conclusion, the present findings suggest a pathway for induction of an altered phenotype or fetal programming. In humans, this may provide a basis for interventions in early life to reduce risk of later metabolic disease.

\section{Acknowledgements}

G. C. B. and M. A. H. are supported by the British Heart Foundation. Collection of human umbilical cord specimens was supported by the Medical Research Council.

\section{References}

Armitage JA, Lakasing L, Taylor PD, Balachandran AA, Jensen RI, Dekou V, Ashton N, Nyengaard JR \& Poston L (2005) Developmental programming of aortic and renal structure in offspring of rats fed fat-rich diets in pregnancy. $J$ Physiol. 565, 171-184.

Bateson P, Barker D, Clutton-Brock T, Deb D, D'Udine B, Foley RA, Gluckman P, Godfrey K, Kirkwood T, Lahr MM, McNamara J, Metcalfe NB, Monaghan P, Spencer HG \& Sultan SE (2004) Developmental plasticity and human health. Nature 430, 419-421.

Benvenisty N, Mencher D, Meyuhas O, Razin A \& Reshef L (1985) Sequential changes in DNA methylation patterns of the rat phosphoenolpyruvate carboxykinase gene during development. Proc Natl Acad Sci USA 82, 267-271.

Bertram C, Trowern AR, Copin N, Jackson AA \& Whorwood CB (2001) The maternal diet during pregnancy programs altered expression of the glucocorticoid receptor and type 211 betahydroxysteroid dehydrogenase: potential molecular mechanisms underlying the programming of hypertension in utero. Endocrinology 142, 2841-2853.

Bird A (2001) DNA methylation patterns and epigenetic memory. Genes Dev 16, 6-21.

Biniszkiewicz D, Gribnau J, Ramsahoye B, Gaudet F, Eggan K, Humpherys D, Mastrangelo MA, Jun Z, Walter J \& Jaenisch R (2002) Dnmt1 overexpression causes genomic hypermethylation, loss of imprinting, and embryonic lethality. Mol Cell Biol 22, 2124-2135.

Boyd KE \& Farnham P (1999) Coexamination of site-specific transcription factor binding and promoter activity in living cells. Mol Cell Biol 19, 8393-8399.

Burdge GC, Phillips ES, Dunn RL, Jackson AA \& Lillycrop KA (2004) Effect of reduced maternal protein consumption during pregnancy in the rat on plasma lipid concentrations and expression of peroxisomal proliferator-activated receptors in the liver and adipose tissue of the offspring. Nutr Res 24, 639-646.

Burns SP, Desai M, Cohen RD, Hales CN, Iles RA, Germain JP, Going TC \& Bailey RA (1997) Gluconeogenesis, glucose handling, and structural changes in livers of the adult offspring of rats partially deprived of protein during pregnancy and lactation. J Clin Invest 100, 1768-1774.

Bustin SA (2000) Absolute quantification of mRNA using real-time reverse transcription polymerase chain reaction assays. $J \mathrm{Mol}$ Endocrinol 25, 169-193.
Desai M, Byrne CD, Meeran K, Martenz ND, Bloom SR \& Hales CN (1997) Regulation of hepatic enzymes and insulin levels in offspring of rat dams fed a reduced-protein diet. Am J Physiol 273, G899-G904.

Detich N, Theberge J \& Szyf M (2002) Promoter-specific activation and demethylation by MBD2/demethylase. J Biol Chem 277, 35791-35794.

Fuks F, Hurd PJ, Wolf D, Nan X, Bird AP \& Kouzarides T (2003) The methyl-CpG-binding protein MeCP2 links DNA methylation to histone methylation. J Biol Chem 278, 4035-4040.

Ghoshal K, Li X, Datta J, Bai S, Pogribny I, Pogribny M, Huang Y, Young D \& Jacob ST (2006) A folate- and methyl-deficient diet alters the expression of DNA methyltransferases and methyl $\mathrm{CpG}$ binding proteins involved in epigenetic gene silencing in livers of F344 rats. J Nutr 136, 1522-1527.

Gidekel S \& Bergman Y (2002) A unique developmental pattern of Oct-3/4 DNA methylation is controlled by a cis-demodification element. J Biol Chem 277, 34521-34530.

Godfrey KM \& Barker DJ (2001) Fetal programming and adult health. Public Health Nutr 4, 611-624.

Godfrey K, Walker-Bone K, Robinson S, Taylor P, Shore S, Wheeler T \& Cooper C (2001) Neonatal bone mass: influence of parental birthweight, maternal smoking, body composition, and activity during pregnancy. J Bone Min Res 16, 1694-1703.

Grainger RM, Hazard-Leonards RM, Samaha F, Hougan LM, Lesk MR \& Thomsen GH (1983) Is hypomethylation linked to activation of delta-crystallin genes during lens development? Nature 306, 88-91.

Harris RG, White E, Phillips ES \& Lillycrop KA (2002) The expression of the developmentally regulated proto-oncogene Pax3 is modulated by N-Myc. J Biol Chem 277, 34815-34825.

Hershko AY, Kafri T, Fainsod A \& Razin A (2003) Methylation of HoxA5 and HoxB5 and its relevance to expression during mouse development. Gene 302, 65-72.

Jackson AA, Dunn RL, Marchand MC \& Langley-Evans SC (2002) Increased systolic blood pressure in rats induced by a maternal low-protein diet is reversed by dietary supplementation with glycine. Clin Sci (Lond) 103, 633-639.

James SJ, Melnyk S, Pogribna M, Pogribny IP \& Caudill MA (2002) Elevation in S-adenosylhomocysteine and DNA hypomethylation: potential epigenetic mechanism for homocysteine-related pathology. J Nutr 132, Suppl, 2361S-2366S.

Kwong WY, Wild AE, Roberts P, Willis AC \& Fleming TP (2000) Maternal undernutrition during the preimplantation period of rat development causes blastocyst abnormalities and programming of postnatal hypertension. Development 127, 4195-4202.

Lachner M, O'Carroll D, Rea S, Mechtler K \& Jenuwein T (2001) Methylation of histone $\mathrm{H} 3$ lysine 9 creates a binding site for HP1 proteins. Nature 410, 116-120.

Langley SC \& Jackson AA (1994) Increased systolic blood pressure in adult rats induced by fetal exposure to maternal low protein diets. Clin Sci (Lond) 86, 217-222.

Langley-Evans SC (1997) Hypertension induced by fetal exposure to a maternal low-protein diet, in the rat, is prevented by pharmacological blockade of maternal glucocorticoid synthesis. J Hypertens 15, 537-544.

Langley-Evans SC, Gardner DS \& Jackson AA (1996) Maternal protein restriction influences the programming of the rat hypothalamic-pituitary-adrenal axis. J Nutr 126, 1578-1585.

Leu YW, Rahmatpanah F, Shi H, Wei SH, Liu JC, Yan PS \& Huang TH (2003) Double RNA interference of DNMT3b and DNMT1 enhances DNA demethylation and gene reactivation. Cancer Res 63, 6110-6115.

Lillycrop KA, Phillips ES, Jackson AA, Hanson MA \& Burdge GC (2005) Dietary protein restriction of pregnant rats induces and folic acid supplementation prevents epigenetic modification of hepatic gene expression in the offspring. J Nutr 135, 1382-1386. 
Litt MD, Simpson M, Gaszner M, Allis CD \& Felsenfeld G (2001) Correlation between histone lysine methylation and developmental changes at the chicken beta-globin locus. Science 293, 2453-2455.

Maloney CA, Gosby AK, Phuyal JL, Denyer GS, Bryson JM \& Caterson ID (2003) Site-specific changes in the expression of fatpartitioning genes in weanling rats exposed to a low-protein diet in utero. Obes Res 11, 461-468.

McCormick JA, Lyons V, Jacobson MD, Noble J, Diorio J, Nyirenda M, Weaver S, Ester W, Yau JL, Meaney MJ, Seckl JR \& Chapman KE (2000) 5'-Heterogeneity of glucocorticoid receptor messenger RNA is tissue specific: differential regulation of variant transcripts by early-life events. Mol Endocrinol 14, 506-517.

Milutinovic S, Zhuang Q, Niveleau A \& Szyf M (2003) Epigenomic stress response. Knockdown of DNA methyltransferase 1 triggers an intra-S-phase arrest of DNA replication and induction of stress response genes. $J$ Biol Chem 278, $14985-14995$.

Nakayama J, Rice JC, Strahl BD, Allis CD \& Grewal SI (2001) Role of histone H3 lysine 9 methylation in epigenetic control of heterochromatin assembly. Science 292, 110-113.

Nyirenda MJ, Lindsay RS, Kenyon CJ, Burchell A \& Seckl JR (1998) Glucocorticoid exposure in late gestation permanently programs rat hepatic phosphoenolpyruvate carboxykinase and glucocorticoid receptor expression and causes glucose intolerance in adult offspring. J Clin Invest 101, 2174-2181.

Petrie L, Duthie SJ, Rees WD \& McConnell JM (2002) Serum concentrations of homocysteine are elevated during early pregnancy in rodent models of fetal programming. Br J Nutr 88, 471-477.

Ravelli AC, van der Meulen JH, Michels RP, Osmond C, Barker DJ, Hales CN \& Bleker OP (1998) Glucose tolerance in adults after prenatal exposure to famine. Lancet 351, 173-177.

Reik W, Dean W \& Walter J (2001) Epigenetic reprogramming in mammalian development. Science 293, 1089-1093.

Remacle C, Bieswal F \& Reusens B (2004) Programming of obesity and cardiovascular disease. Int J Obes Relat Metab Disord 28, Suppl 3, S46-S53.

Rhee I, Jair KW, Yen RW, Lengauer C, Herman JG, Kinzler KW, Vogelstein B, Baylin SB \& Schuebel KE (2000) CpG methylation is maintained in human cancer cells lacking DNMT1. Nature 404, $1003-1007$.

Robertson KD, Ait-Si-Ali S, Yokochi T, Wade PA, Jones PL \& Wolffe AP (2000) Dnmt1 forms a complex with Rb, E2F1 and HDAC1 and represses transcription from E2F-responsive promoters. Nat Genet 25, 338-342.

Stancheva I, Hensey C \& Meehan RR (2001) Loss of the maintenance methyltransferase, xDnmt1, induces apoptosis in Xenopus embryos. EMBO J 20, 1963-1973.

Stancheva I \& Meehan RR (2000) Transient depletion of xDnmt1 leads to premature gene activation in Xenopus embryos. Genes Dev 14, 313-327.

Strahl BD, Ohba R, Cook RG \& Allis CD (1999) Methylation of histone $\mathrm{H} 3$ at lysine 4 is highly conserved and correlates with transcriptionally active nuclei in Tetrahymena. Proc Natl Acad Sci USA 96, 14967-14972.

Terzolo M, Allasino B, Bosio S, Brusa E, Daffara F, Ventura M, Aroasio E, Sacchetto G, Reimondo G, Angeli A \& Camaschella C (2004) Hyperhomocysteinemia in patients with Cushing's syndrome. J Clin Endocrinol Metab 89, 3745-3751.

Torrens C, Brawley L, Anthony FW, Dance CS, Dunn R, Jackson AA, Poston L \& Hanson MA (2006) Folate supplementation during pregnancy improves offspring cardiovascular dysfunction induced by protein restriction. Hypertension 47, 982-987.

Turner BM (2000) Histone acetylation and an epigenetic code. Bioessays 22, 836-845.

Turner JD \& Muller CP (2005) Structure of the glucocorticoid receptor $(\mathrm{NR} 3 \mathrm{C} 1)$ gene $5^{\prime}$ untranslated region: identification, and tissue distribution of multiple new human exon 1. J Mol Endocrinol 35, 283-292.

Vickers MH, Gluckman PD, Coveny AH, Hofman PL, Cutfield WS, Gertler A, Breier BH \& Harris M (2005) Neonatal leptin treatment reverses developmental programming. Endocrinology 146, 4211-4216.

Zegerman P, Canas B, Pappin D \& Kouzarides T (2002) Histone H3 lysine 4 methylation disrupts binding of nucleosome remodeling and deacetylase (NuRD) repressor complex. J Biol Chem 277, $11621-11624$. 